\title{
LEACHING CHARACTERISTICS OF THE FINE FRACTION FROM AN EXCAVATED LANDFILL: PHYSICO-CHEMICAL CHARACTERIZATION
}

\author{
Fabio Kaczala ${ }^{a}$, \\ Hadi Mehdinejad ${ }^{b}$, \\ Allar Lääne ${ }^{c}$, \\ Kaja Orupõld ${ }^{c}$, \\ Amit Bhatnagar ${ }^{a}$, \\ Mait Kriipsalu ${ }^{c}$, \\ William Hogland $^{a}$ \\ ${ }^{a}$ Linnaeus University - LNU \\ ${ }^{\boldsymbol{b}}$ Golestan University of Medical Sciences, Iran \\ ${ }^{c}$ Estonian University of Life Sciences
}

\begin{abstract}
This investigation was focused on the physico-chemical characterization of the leachate generated by the fine fraction $(<10 \mathrm{~mm})$ of excavated waste from full-scale landfill mining project. The samples were taken in the Kudjape Landfill, Saarema Island, Estonia in four different test pits $\left(\mathrm{TP}_{1}, \mathrm{TP}_{2}, \mathrm{TP}_{3}, \mathrm{TP}_{4}\right)$ that were divided in four different layers $\left(\mathrm{L}_{1}, \mathrm{~L}_{2}, \mathrm{~L}_{3}, \mathrm{~L}_{4}\right)$. Total chemical oxygen demand (CODt), dissolved chemical oxygen demand (CODd), total organic carbon (TOC), dissolved organic carbon (DOC) and metals $(\mathrm{Zn}, \mathrm{Cu}, \mathrm{Pb}$ and $\mathrm{Cd}$ ) were analyzed. The results have shown that most of the COD fraction released into the water (approximately 70\%) was in particulate/colloidal state. The TOC released ranged between 3,530$\mathrm{mg} / \mathrm{kg}$ dry matters and 2,326 mg/kg dry matter for test pits. Dissolved organic matter (DOC) had concentrations ranging between 365-874 $\mathrm{mg} / \mathrm{kg}$ and $317-940 \mathrm{mg} / \mathrm{kg}$ for different test pits and sampling layers respectively. Very low average leaching rates (\%) of metals were observed with leaching ranging between $0.2 \%$ and $1.5 \%$ which might be explained by the lower solubility of these metals in alkaline pHs. $\mathrm{Pb}$ had a significantly higher average leaching rate $(1.0 \%)$ in comparison to $\mathrm{Zn}(0.70 \%)$ and $\mathrm{Cu}(0.35 \%)$. This study also showed the potential use of $\mathrm{COD}_{\mathrm{t}}$ as a surrogate indicator of organic carbon in both suspended and dissolved forms (TOC and DOC) and also $\mathrm{Zn}$ on the basis of high correlation coefficients observed. To conclude, the proposal and implementation of adequate management strategies that minimize environmental impacts and take advantages of the beneficial use of fine-grained fractions in landfill mining rely on detailed physico-chemical characterization of both the fine fractions itself and the leachate generated during storage and use.
\end{abstract}

\section{KEY WORDS:}

Landfill mining; Fine fraction; Leachate; heavy metals; TOC; DOC

https://doi.org/10.15626/Eco-Tech.2014.010 


\section{INTRODUCTION}

Landfilling has been one of the most dominant ways of solid waste disposal in many parts of the world (Laner et al., 2012; Masi et al., 2014), although there is a clear decreasing trend in recent years. Landfills pose enormous risks to human health and the environment as a consequence of gaseous emissions of volatile organic compounds, methane, carbon dioxide, airborne particulate matter (Slack et al., 2005) and also the generation of leachate. Despite the closure of landfills, threats for the environment and human health still remain for a long period (Long et al., 2011). However, a contradiction in relation to landfills is that as environmental and human health concerns have been constantly raised, landfills can also be viewed as a secondary source of materials (plastics, glass and metals) and energy (direct collection of methane or energy recovery through incineration of materials with high calorific values such as plastics). At the same time, global demand for raw materials has tremendously increased in the past few decades resulting in both higher costs and increased environmental impacts during extraction, processing and use (Kaartinen et al., 2013). Therefore, there is a need for the implementation of new models of resource management that combine the current challenges of high demands and overexploitation of natural resources and materials scarcity and environmental problems caused by landfills.

As stated by Krook and Baas (2013) landfill excavation/mining initiatives taking place in the 1980 's and 90's were mainly addressed to solve landfill management issues such as lack of landfill void space, local pollution concerns and interference with urban expansion. However, nowadays, the main motivation for landfill excavation/mining can be the possibilities of resource recovery, and as the main focus has shifted towards material and energy recovery, it is of crucial importance to have a detailed knowledge of both waste composition of the landfill to be excavated and further treatability/processing and destination in early stages of the project implementation.

Several studies have addressed waste characterization primarily by screening the waste into different particle sizes followed by manual sorting into different waste categories (Hogland, 2002; Hull et al., 2005; Kaartinen et al., 2013; Kurian et al., 2003). One of the main findings obtained from waste characterization has been reported by Hogland (2002), which states that fine fraction $(<18 \mathrm{~mm})$ can contribute to more than $50 \%$ of the total mass of an excavated landfill. However, the composition of fine fraction and also the potential environmental and ecological disturbances are rarely studied and reported in the literature. The leaching and release of chemical constituents from the fine fraction upon contact with rain water during fine fraction storage and also in the case this is used as cover material of excavated/mined landfills can result in potential risks to the environment. Leaching tests can bring valuable information regarding the compliance with existing standards established for different purposes for instance acceptability for landfilling it back considering the fine fraction is classified as waste and needs to be disposed of. Furthermore, excavated waste must be stored before it reaches the final destination and the knowledge of leaching properties brings also basic information on how to design and implement proper storage areas and stormwater/leachate collection and treatment. Therefore the current research was focused on the physico-chemical characterization of the leachate generated by the fine fraction $(<10 \mathrm{~mm})$ of a full-scale excavated landfill located in Kudjape, Saarema Island, in Estonia. The extent to which the constituents dissolve into the water is site- and material-specific and the composition of the leachate generated from the studied material and its potential to impact water quality will be the key factors in evaluating the potential use of such fine fraction.

\section{MATERIALS AND METHODS}




\subsection{Description of the landfill site}

The fine fraction $(<10 \mathrm{~mm})$ was obtained from landfill mining activities that took place at Kudjape Landfill, located in the Island of Saaremaa (N 58:16:06, E 22:32:23), $2 \mathrm{~km}$ southeast from Kuressaare town, Estonia during February 2013. The landfill received mainly municipal solid wastes since 1970 . Average annual temperature at the site is $5.6^{\circ} \mathrm{C}$ and annual precipitation is $594 \mathrm{~mm}$.

\subsection{Sampling procedures}

The sampling at Kudjape Landfill was done by a tread excavator machine (Volvo EC210B 21 tonnes) with an attached bucket of $1 \mathrm{~m}^{3}$ excavation capacity. Four test pits $\left(T P_{1}, T P_{2}, T P_{3}, T P_{4}\right)$ spatially distributed over the flat top landfill area, which were then divided in four sampling depths $\left(L_{1}, L_{2}, L_{3}, L_{4}\right)$ were excavated. Each test pit had a total excavation depth of approximately $5 \mathrm{~m}$ including the $30-50 \mathrm{~cm}$ topsoil cover layer that was previously removed; thus, each layer had an approximate depth of $1 \mathrm{~m}$, and sample volume of $1 \mathrm{~m}^{3}$. An example of one test pit and respective sampling layers is illustrated in Figure 1.

As soon as $1 \mathrm{~m}^{3}$ of waste was excavated from each layer within a specific test pit, the waste was fed into a trommel screen Doppstadt SM518 for an initial separation of the waste in two fractions: 1) $>40 \mathrm{~mm}$ and 2) $<40 \mathrm{~mm}$. The fraction $<40 \mathrm{~mm}$ was further screened down to $<10$ $\mathrm{mm}$ which was the fraction (fine-grained fraction) used for the leaching tests reported in this study. Considering four test pits with samples taken in four different layers, a total of 16 samples of fine fraction, approximately $10 \mathrm{~L}$ each, were transported to the laboratory and stored under $4^{\circ} \mathrm{C}$ until the leaching tests were performed.

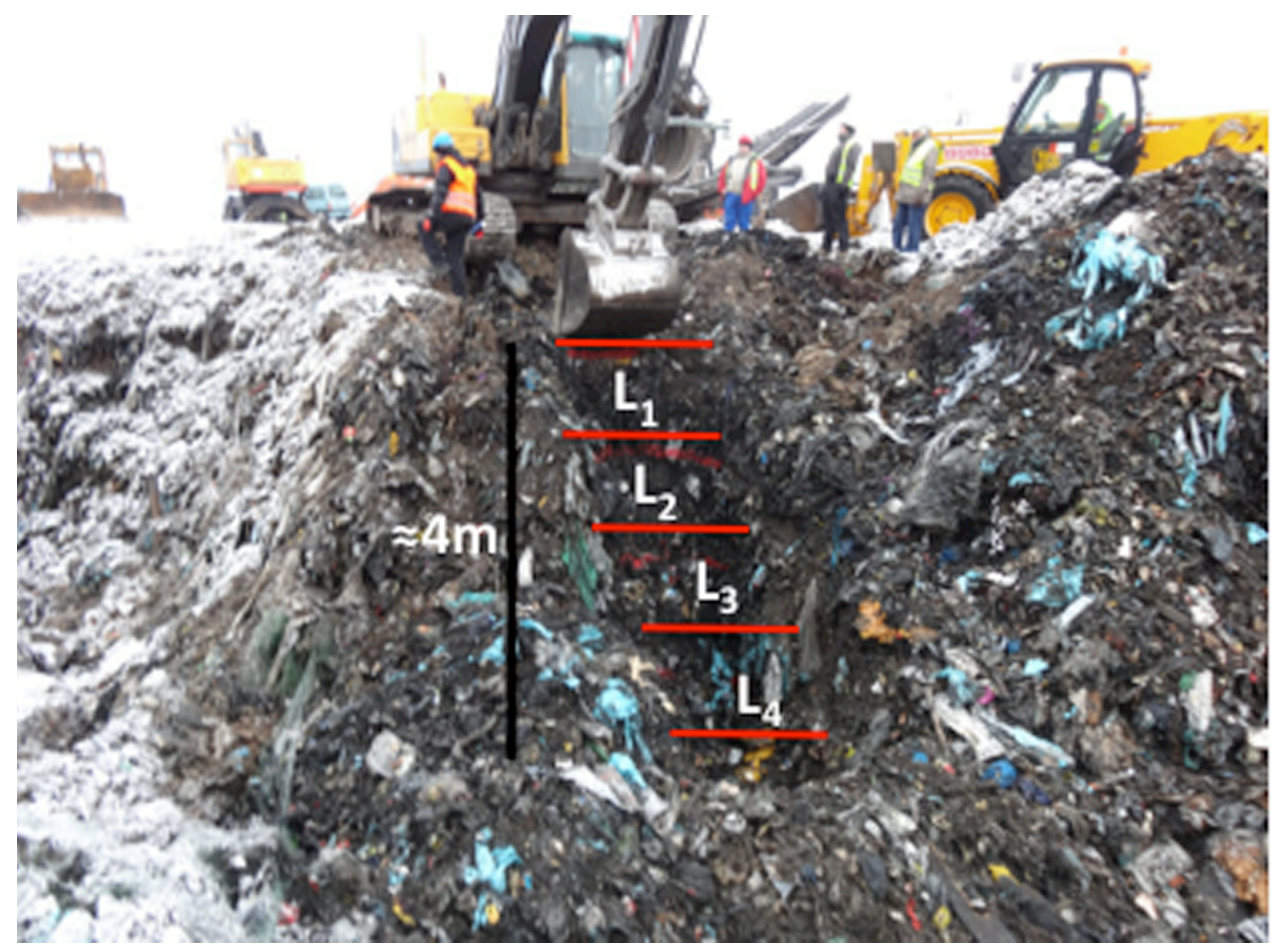

Figure 1. Excavation of test pit $1\left(T P_{1}\right)$ with excavation layers are indicated with red lines. 


\subsection{Sample preparation for the leaching tests}

Leaching tests were done with eight composite sub-samples from the test pits $\left(\underline{T P_{x}}\right)$ and the different sampling layers $\left(L_{x}\right)$ that were obtained as follows (Eq. 1 and 2):

$$
\begin{array}{lr}
T P_{X}=L_{1 X}+L_{2 X}+L_{3 X}+L_{4 X} & \text { Eq. } 1 \\
L_{X}=T P_{1 X}+T P_{2 X}+T P_{3 X}+T P_{4 X} & \text { Eq. } 2
\end{array}
$$

Where $X$ is the number of the test pit ( 1 to 4 ) and the layers (1 to 4 ) respectively.

\subsection{Leaching test}

The batch-leaching tests were carried out according to the Swedish Standard Method SS-EN 12457-2 with minor modifications with a liquid/solid ratio $(\mathrm{L} / \mathrm{S})$ of $10 \mathrm{~L} / \mathrm{kg}$. The tests were carried out in a flocculator/jar test (STUART-SW6) for $24 \mathrm{~h}$ under agitation speed of $100 \mathrm{rpm}$ in $800 \mathrm{~mL}$ beakers at ambient temperature $\left(23 \pm 1^{\circ} \mathrm{C}\right)$. After $24 \mathrm{~h}$ agitation, the fine fraction settled down for 30 min and samples from the supernatant phase (eluent) were taken for further physicochemical characterization. Eluents were stored in $50 \mathrm{~mL}$ falcon tubes at $4^{\circ} \mathrm{C}$ for total organic carbon (TOC), dissolved organic carbon (DOC), total chemical oxygen demand $\left(\mathrm{COD}_{\mathrm{t}}\right)$, dissolved chemical oxygen demand $\left(\mathrm{COD}_{\mathrm{d}}\right)$ and metal analysis $(\mathrm{Zn}, \mathrm{Cu}$ and $\mathrm{Pb})$. Falcon tubes that received eluents for metal analysis were previously acid-washed (0.1 M nitric acid). All leaching tests were performed in triplicates.

\subsection{Analytical procedures}

Physico-chemical characterization of the leachate was done for: $\mathrm{COD}_{\mathrm{t}}, \mathrm{COD}_{\mathrm{d}}$, TOC, DOC and the metals zinc $(\mathrm{Zn})$, copper $(\mathrm{Cu})$, lead $(\mathrm{Pb})$ and cadmium $(\mathrm{Cd})$. Prior to the analysis of $\mathrm{COD}_{\mathrm{d}}$ and DOC, samples were filtered through a GF/C Whatman filter $1.2 \mu \mathrm{m}$ (Cat No 1822-047). All parameters with the exception of metals were analyzed with Dr. Lange cuvette tests (Dr. Bruno Lange, GmbH \& CO. KG, Dusseldorf, Germany) and measured spectrophotometrically with a $\mathrm{HACH}$ XION 500 spectrophotometer (DR $5000 \mathrm{HACH}$ ). The metals $\mathrm{Zn}, \mathrm{Cu}, \mathrm{Pb}$ and $\mathrm{Cd}$ in leachates were analyzed after filtration through $0,45 \mu \mathrm{m}$ filters attached to $50 \mathrm{ml}$ syringes by atomic absorption spectroscopy - AAS (Model Analyst 4). Analysis of Cd was performed using atomic absorption spectrophotometer (AA-6800, Shimadzu) equipped with graphite furnace atomizer (GFA-EX7). The Quantification of the selected metals in the fine fraction (solid phase) was performed with a portable Olympus DELTA DS-4000 Handheld X-ray Analyzer (Olympus).

\section{RESULTS AND DISCUSSION}

\subsection{Total chemical oxygen demand $\left(C O D_{t}\right)$ and dissolved chemical oxygen demand $\left(C O D_{d}\right)$}

As it can be observed in the Figure $2 \mathrm{a}$, the $\mathrm{COD}_{\mathrm{t}}$ of the leachate extracted in all test pits were significantly different $(\mathrm{p}<0.05)$ and ranged between $4,924 \mathrm{mg} / \mathrm{kg}$ and 7,622 $\mathrm{mg} / \mathrm{kg}$ (Figure 2a). $\mathrm{TP}_{4}$ and $\mathrm{TP}_{3}$ were the ones with the lowest and the highest amounts of $\mathrm{COD}_{\mathrm{t}}$ released per unit mass of dry fine fraction respectively. The $\mathrm{COD}_{\mathrm{t}}$ released from the different layers were also significantly different $(\mathrm{p}<0.05)$ and whereas the highest $\mathrm{COD}_{\mathrm{t}}$ was observed in the deeper layers with $7,543 \mathrm{mg} / \mathrm{kg}$ and $5,520 \mathrm{mg} / \mathrm{kg}$ released by $\mathrm{L}_{3}$ and $\mathrm{L}_{4}$ respectively (Figure 2c), upper layers $\left(\mathrm{L}_{1}\right.$ and $\left.\mathrm{L}_{2}\right)$ released $\mathrm{COD}_{\mathrm{t}}$ values as low as $3,623 \mathrm{mg} / \mathrm{kg}$ and $3,572 \mathrm{mg} / \mathrm{kg}(\mathrm{p}>0.05)$. The Figure 2

illustrates the amounts of $\mathrm{COD}_{\mathrm{d}}$ released into the solution and values ranging between $651 \mathrm{mg} / \mathrm{kg}$ 
and $1904 \mathrm{mg} / \mathrm{kg}$ for test pits (Figure 2b) and $455 \mathrm{mg} / \mathrm{kg}$ and $1561 \mathrm{mg} / \mathrm{kg}$ for different sampling layers (Figure $2 \mathrm{~d}$ ). The amounts of $\mathrm{COD}_{\mathrm{d}}$ corresponded to $28 \%, 14 \%, 16 \%$ and $13 \%$ of the $\mathrm{COD}_{\mathrm{t}}$ in $\mathrm{TP}_{1}, \mathrm{TP}_{2}, \mathrm{TP}_{3}$ and $\mathrm{TP}_{4}$ respectively (Figure 3a). The highest contribution of dissolved matter was observed in the leachate of $\mathrm{TP}_{1}(28 \%)$ and this might be related to the specific environmental conditions of the excavated area. Oxygen diffusion is a factor that enhances the hydrolysis and the transformation of suspended macromolecular substances into lower molecular weight matters (Ziyang et al., 2009), which might have caused the current observation.

Considering the amount of $\mathrm{COD}_{\mathrm{d}}$ in comparison of $\mathrm{COD}_{\mathrm{t}}$, values as low as those observed for test pits were observed in the leachate of the different sampling layers with corresponding values of $\mathrm{COD}_{\mathrm{d}}$ ranging between $12 \%$ and $20 \%$ of $\mathrm{COD}_{\mathrm{t}}$ (Figure $3 \mathrm{~b}$ ). The low contribution of only $12 \%$ in the upper layer $\left(\mathrm{L}_{1}\right)$ might be due to the relatively young age of the excavated waste (approximately 10 years old waste) with short time for hydrolysis to take place. However it is important to emphasize that the types of waste discarded in a landfill do not solely determine the leachate composition and existing conditions in the waste body such as chemical and biological transformations and also interactions of contaminants with plant-derived matter need to be considered (Slack et al., 2005).

(a)

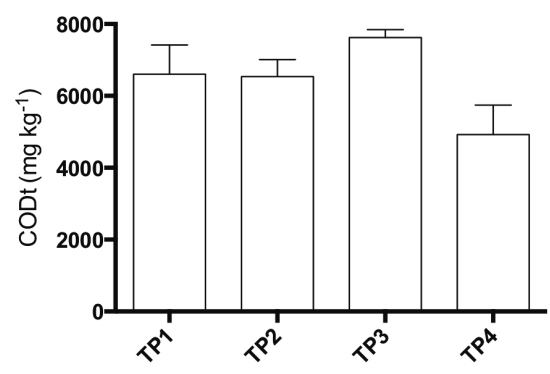

(c)

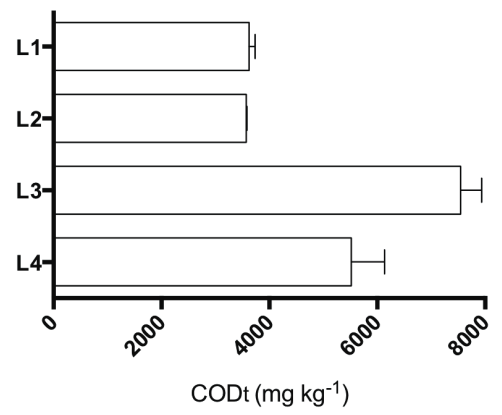

(b)

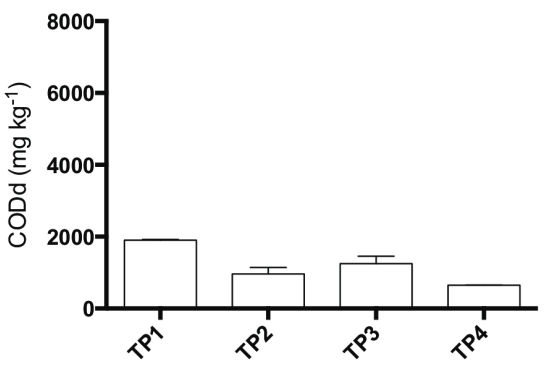

(d)

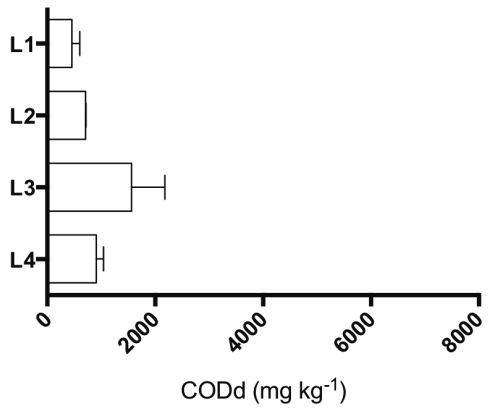

Figure 2. $C O D_{t}$ and $C O D_{d}$ leached per unit mass of waste $\left(\mathrm{mg} \mathrm{kg}^{-1}\right)$ in samples taken from the different test pits and layers. $(n=3)$. 
(a)

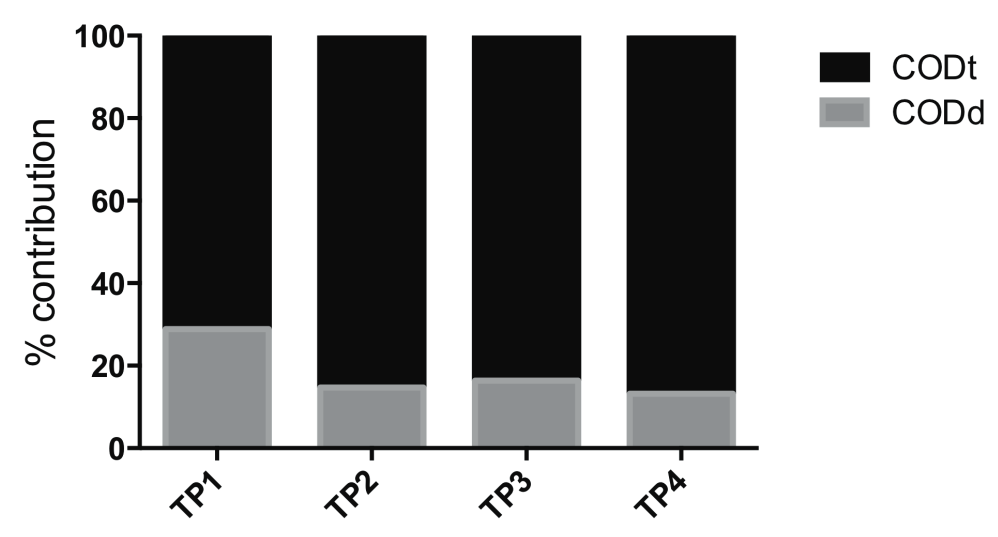

(b)

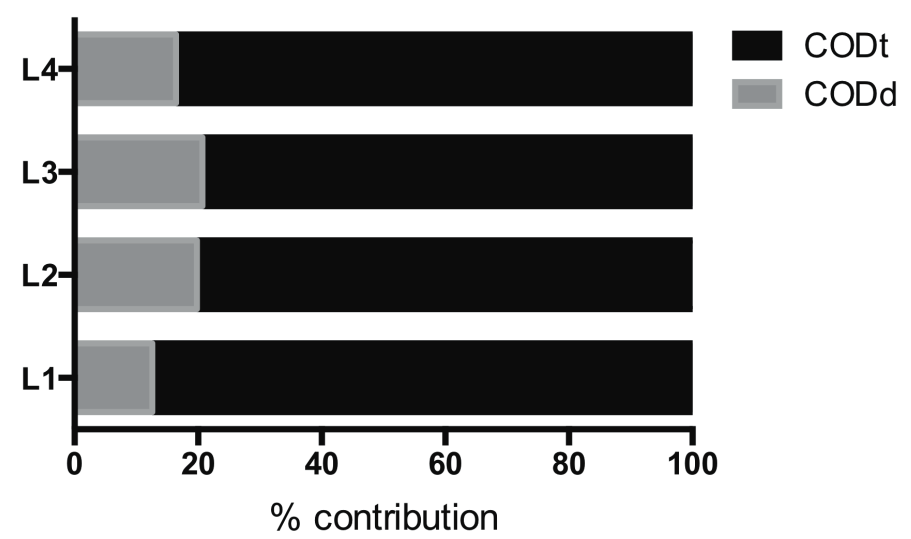

Figure 3. Partial contribution of $C O D_{d}$ in relation to $C O D_{t}$ different test pits and layers.

\subsection{Total organic carbon and dissolved organic carbon}

There was a significant difference observed in TOC between all test pits $(\mathrm{p}<0.05)$ with $\mathrm{TP}_{3}$ releasing significantly higher amounts of TOC $(3,530 \mathrm{mg} / \mathrm{kg}$ dry matter $)$ in comparison to $\mathrm{TP}_{1}$ $(2,519 \mathrm{mg} / \mathrm{kg}$ dry matter $)$ and $\mathrm{TP}_{4}(2,326 \mathrm{mg} / \mathrm{kg}$ dry matter $)$ suggesting different stages of biodegradation processes spatially distributed within the excavated landfill. Considering the layers, as illustrated in Figure 5c, values as high as $3,069 \mathrm{mg} / \mathrm{kg}$ and $2,470 \mathrm{mg} / \mathrm{kg}$ of TOC were observed for $\mathrm{L}_{3}$ and $\mathrm{L}_{4}$ respectively in comparison to values as low as $1,894 \mathrm{mg} / \mathrm{kg}$ and 1,999 $\mathrm{mg} / \mathrm{kg}$ for upper and intermediate layers $\left(\mathrm{L}_{1}\right.$ and $\left.\mathrm{L}_{2}\right)$.

Dissolved organic matter was evaluated as DOC and concentrations ranging between 365-874 $\mathrm{mg} / \mathrm{kg}$ and $317-940 \mathrm{mg} / \mathrm{kg}$ for different test pits (Figure $4 \mathrm{~b}$ ) and sampling layers (Figure $4 \mathrm{~d}$ ) respectively were observed. The highest leaching of DOC was observed for $\mathrm{TP}_{1}$ and $\mathrm{L}_{3}$ with concentrations as high as $874 \mathrm{mg} / \mathrm{kg}$ and $940 \mathrm{mg} / \mathrm{kg}$, being significantly higher than the others $(\mathrm{p}<0.05)$.

Considering $\mathrm{TP}_{1}$, the low TOC observed might be related to a higher rate of hydrolysis and further degradation, a fact that is corroborated by $38 \%$ of the total carbon content being in hydrolyzed phase (Figure 5a). This highlights that even though material composition within a 
specific landfill does not vary, environmental and physical conditions such as oxygen diffusion, moisture content, void space and waste compactness can play important roles in the leachate generated and concentrations of carbon contents in particulate and dissolved forms. However, it is important to emphasize that dynamics of organic matter transformation and mineralization in landfills is relatively complex and highly dependent on the environmental conditions (Parodi et al, 2011) and whether chemistry or biology controls the solubility of organic matter and how different factors interact is not well known yet and further investigation is required.

(a)

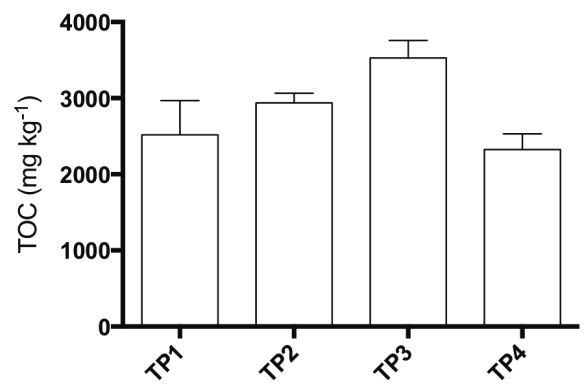

(c)

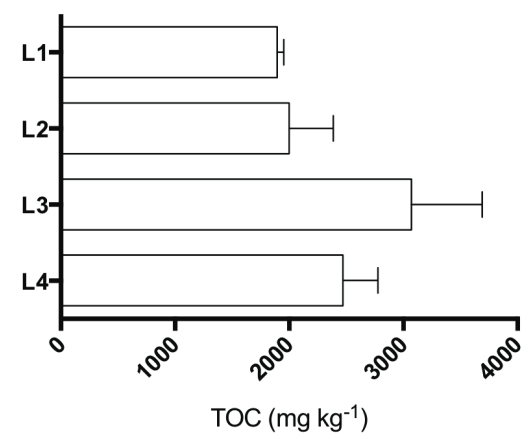

(b)

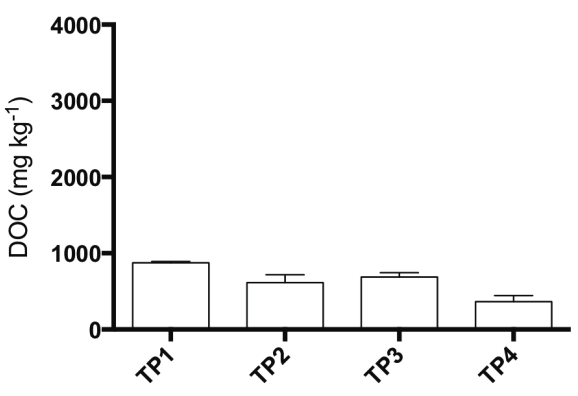

(d)

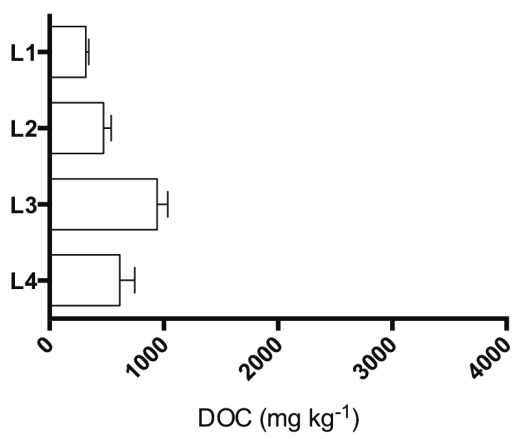

Figure 4. TOC and DOC leached per unit mass of waste (mg kg-1) in samples taken from the different layers and test pits. $(n=3)$. 
(a)

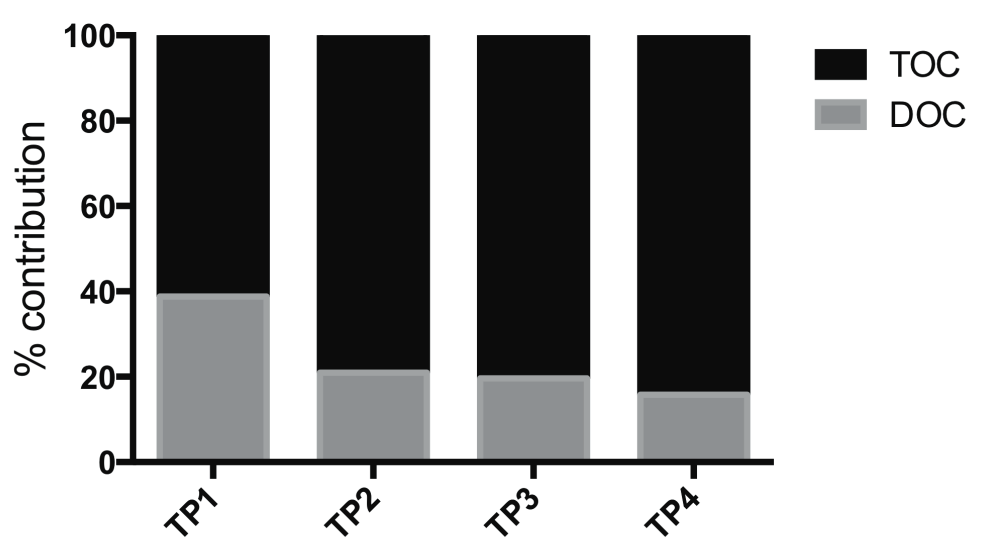

(b)

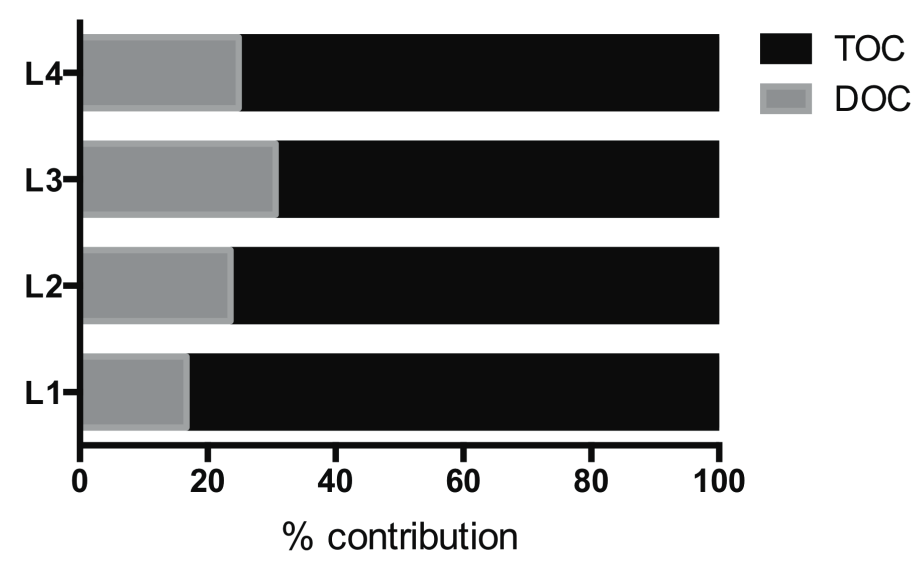

Figure 5. Partial contribution of DOC in relation to the TOC in different test pits and layers.

\subsection{Metals}

As observed in the Figure 6, the amounts of $\mathrm{Zn}, \mathrm{Pb}$ and $\mathrm{Cu}$ released by unit mass in different test pits ranged between 3.19-6.85, 0.90-1.35 and $0.13-0.40 \mathrm{mg} / \mathrm{kg}$ respectively whereas released $\mathrm{Cd}$ was as low as $1.00-3.00 \mu \mathrm{g} / \mathrm{kg}$. A comparison of the metals released by the different test pits has shown that metals were significantly different among them (One-way ANOVA $p<0.05$ ) and considering $\mathrm{TP}_{3}$, a statistically higher amount of $\mathrm{Zn}$ was released in comparison to the others. Furthermore, the amounts of $\mathrm{Cu}$ released were significantly different $(\mathrm{p}<0.05)$ in the following order: $\mathrm{TP}_{4}<\mathrm{TP}_{3}<\mathrm{TP}_{2}<\mathrm{TP}_{1}$ (Figure 6e).

Considering the layers, whereas $\mathrm{Zn}$ was released in higher amounts with values ranging between $2.65-6.30 \mathrm{mg} / \mathrm{kg}$ (Figure 6b), Cd was released in concentrations ranging between $2.00-3.00$ $\mu \mathrm{g} / \mathrm{kg}$ (Figure 6h). Intermediate concentrations were observed for $\mathrm{Pb}$ and $\mathrm{Cu}$ with released amounts per unit dry mass as low as $1.00-1.30$ and $0.15-0.18 \mathrm{mg} / \mathrm{kg}$ respectively (Figure $6 \mathrm{~d}$ and 6f). Although the obtained results did not show any well-defined pattern in relation to upper and deeper layers $\mathrm{Zn}, \mathrm{Pb}, \mathrm{Cu}$ and $\mathrm{Cd}$ were significantly different when comparing the different sampling layers (One-way ANOVA, $\mathrm{p}<0.05$ ). By analyzing the results based only on 
concentration released into the aqueous phase one can either overestimate or underestimate the mobility of certain chemical constituents into the water and potential environmental impacts. Therefore leaching rates (\%) of each metal was calculated on the basis of the concentrations found in the solid phase and actual concentrations detected on the artificial leachate (Table 1). According to Table 1, very low average leaching rates (\%) ranging between $0.2 \%$ and $1.5 \%$ were observed which might be explained by the lower solubility of these metals in alkaline pHs resulting in negligible concentrations in the artificial leachate. Low leaching rates (\%) of metal as observed in this study has been highlighted by Slack et al. (2005) that have reported leaching rates of disposed metals in landfills within the first 30 years as low as $\leq 0.02 \%$ due to metal immobilization by organic/inorganic sorption and precipitation.

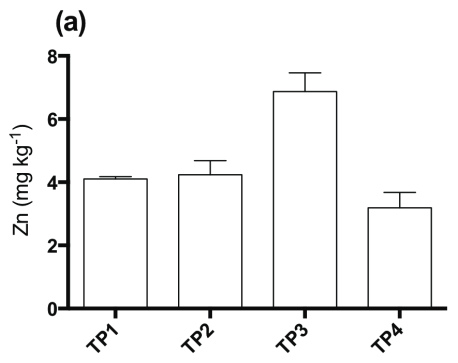

(c)

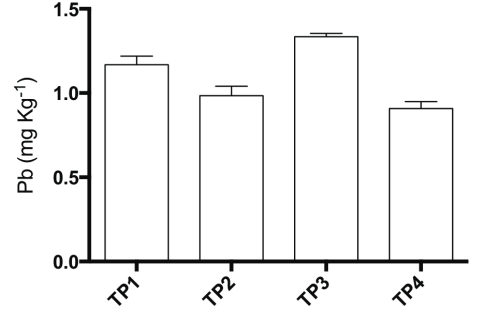

(e)

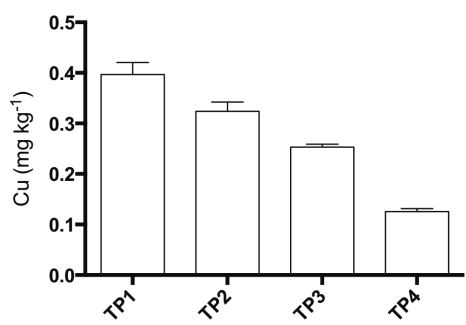

(g)

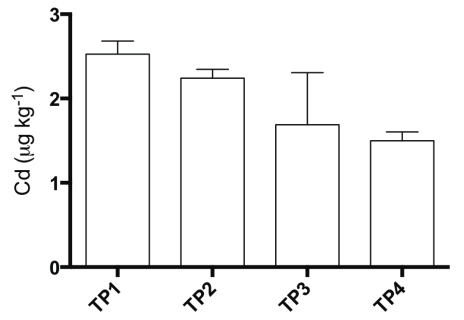

(b)

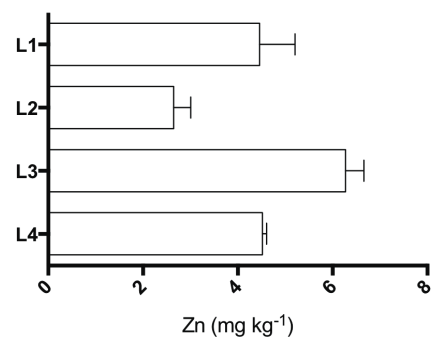

(d)

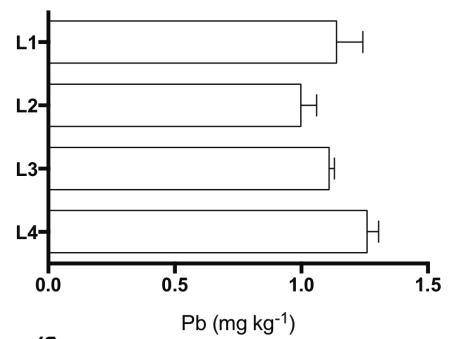

(f)

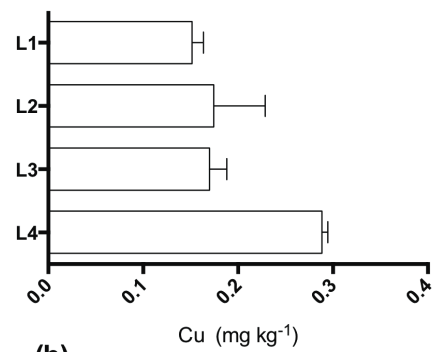

(h)

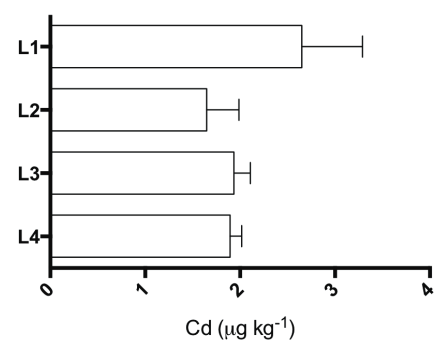

Figure 6. The amounts of metals $\mathrm{Zn}, \mathrm{Pb}, \mathrm{Cu}(\mathrm{mg} \mathrm{kg}-1)$ and $\mathrm{Cd}(\mu \mathrm{g} \mathrm{kg}-1)$ leached per unit mass of waste in samples taken from the different test pits and layers. $(n=3)$. 
Table 1. The concentration of studied metals in the solid matrix, aqueous phase and respective leaching rates (\%) of studied metals in different locations (test pits) and layers of the excavated landfill.

\begin{tabular}{c|ccc|ccc|ccc|}
\hline & \multicolumn{3}{|c|}{$\mathrm{Cu}\left(\mathrm{mg} \mathrm{kg}^{-1}\right)$} & \multicolumn{3}{c|}{$\mathrm{Zn}\left(\mathrm{mg} \mathrm{kg}^{-1}\right)$} & \multicolumn{3}{c|}{$\mathrm{Pb}\left(\mathrm{mg} \mathrm{kg}^{-1}\right)$} \\
\cline { 2 - 11 } Sample & $\begin{array}{c}\text { Solid } \\
\text { Phase }\end{array}$ & Leached $\begin{array}{c}\text { Leaching } \\
\text { rate (\%) }\end{array}$ & $\begin{array}{c}\text { Solid } \\
\text { Phase }\end{array}$ & Leached & $\begin{array}{c}\text { Leaching } \\
\text { rate (\%) }\end{array}$ & $\begin{array}{c}\text { Solid } \\
\text { Phase }\end{array}$ & Leached $\begin{array}{c}\text { Leaching } \\
\text { rate (\%) }\end{array}$ \\
\hline TP1 & 105.2 & 0.4 & 0.4 & 845.3 & 4.1 & 0.5 & 119.2 & 1.2 & 1.0 \\
\cline { 2 - 11 } TP2 & 86.3 & 0.3 & 0.4 & 680.2 & 4.2 & 0.6 & 88.5 & 1.0 & 1.1 \\
\cline { 2 - 11 } TP3 & 45.3 & 0.3 & 0.6 & 732.8 & 6.9 & 0.9 & 147.0 & 1.3 & 0.9 \\
TP4 & 53.4 & 0.1 & 0.2 & 469.0 & 3.2 & 0.7 & 88.3 & 0.9 & 1.0 \\
L1 & 69.5 & 0.2 & 0.2 & 904.7 & 4.5 & 0.5 & 129.0 & 1.1 & 0.9 \\
\cline { 2 - 10 } L2 & 95.4 & 0.2 & 0.2 & 429.8 & 2.6 & 0.6 & 67.3 & 1.0 & 1.5 \\
L3 & 44.5 & 0.2 & 0.4 & 1068.5 & 6.3 & 0.6 & 134.5 & 1.1 & 0.8 \\
L4 & 58.8 & 0.3 & 0.5 & 436.2 & 4.5 & 1.0 & 108.0 & 1.3 & 1.2 \\
\hline
\end{tabular}

* Leaching rate $(\%)=($ Concentration liquid phase* 100$) /($ concentration solid matrix $)$

\section{CONCLUSIONS}

The physico-chemical characteristics of the artifical leachate of the fine fraction $(<10 \mathrm{~mm})$ of a full-scale excavated landfill located in the city of Kudjape, Saarema Island, in Estonia was investigated. Eluents were analysed for TOC, DOC, $\mathrm{COD}_{\mathrm{t}}, \mathrm{COD}_{\mathrm{d}}$ and metals $(\mathrm{Zn}, \mathrm{Cu}, \mathrm{Pb}$ and $\mathrm{Cd})$. The highest $\mathrm{COD}_{\mathrm{t}}$ values were observed in the deeper layers with 7,543 $\mathrm{mg} / \mathrm{kg}$ and 5,520 $\mathrm{mg} / \mathrm{kg}$ released by $\mathrm{L}_{3}$ and $\mathrm{L}_{4}$ respectively. On the other hand, $\mathrm{COD}_{\mathrm{t}}$ released from upper layers $\left(\mathrm{L}_{1}\right.$ and $\left.\mathrm{L}_{2}\right)$ were as low as $3,623 \mathrm{mg} / \mathrm{kg}$ and $3,572 \mathrm{mg} / \mathrm{kg}(\mathrm{p}>0.05)$. There was a significant difference observed in TOC between all test pits $(\mathrm{p}<0.05)$ with TP3 releasing significantly higher amounts of TOC $\left(3,530 \mathrm{mg} / \mathrm{kg}\right.$ dry matter) in comparison to $\mathrm{TP}_{1}(2,519 \mathrm{mg} / \mathrm{kg}$ dry matter $)$ and $\mathrm{TP}_{4}(2,326 \mathrm{mg} / \mathrm{kg}$ dry matter) suggesting different stages of biodegradation processes spatially distributed around the excavated landfill. Whereas the amounts of $\mathrm{Zn}, \mathrm{Pb}$ and $\mathrm{Cu}$ released per unit mass of fine fraction ranged between $2.65-6.85,0.90-1.35$ and $0.1-0.4 \mathrm{mg} / \mathrm{kg}$ respectively, considerably lower amounts of $\mathrm{Cd}$ between $1.0-3.0 \mu \mathrm{g} / \mathrm{kg}$ were observed. To conclude, the proposal and implementation of adequate management strategies that minimize environmental impacts and take advantages of the beneficial use of fine fractions $(<10 \mathrm{~mm})$ in landfill mining rely on detailed physico-chemical characterization of both the solid phase itself and the leachate generated during storage and use.

\section{ACKNOWLEDGEMENTS}

The authors would like to acknowledge the financial support from the Swedish Institute - SI and the Environmental Investment Centre in Estonia. We are grateful for the help obtained during the excavation and field work from the MSc and Phd students of Kaunas University of Technology (Department of Environmental Technology), Estonian University of Life Sciences (Institute of Agricultural and Environmental Sciences and the Department of Water Management), University of Latvia (Faculty of Chemistry), Taras Shevchenko National University of Kyiv and Linnaeus 
University (Environmental Science and Engineering Group). The fieldwork would not be done without crucial help of Olavi and Rein-Erik from RTS-Infra Ltd. Many thanks go to the support given by Valdo Liv and Mihkel Paljak.

\section{REFERENCES}

- Cossu, R., Lai, T., 2012. Washing of waste prior to landfilling. Waste Management. 32,869-878.

- Deutsches Institut für Normung e.V. (1986). DIN 38402-51. German standard methods for the examination of water, wastewater and sludge; general information (group A); calibration of analytical methods, evaluation of analytical results and linear calibration functions used to determine the performance characteristics of analytical methods (A51).

- Deutsches Institut für Normung e.V. (1996). DIN 32645. Chemical Analysis - Decision limit, detection limit and determination limit - Estimation in case of repeatability, terms, methods, evaluation.

- Hogland, W., 2002. Remediation of an old landfill site: soil analysis, leachate quality and gas production. Environmental Science and Pollution Research International. 49-54.

- Hull, R.M., Krogmann, U., Strom, P.F., 2005. Composition and characteristics of excavated materials from a New Jersey landfill. Journal of Environmental Engineering. $3,478-490$.

- International Organization of Standardization, 1990. ISO 8466/1. Water quality. Calibration and evaluation of analytical methods and estimation of performance characteristics. Part 1. Statistical evaluation of linear calibration function.

- Kaartinen, T., Sormunen, K., Rintala, J., 2013. Case study on sampling processing and characterization of landfilled municipal solid waste in the view of landfill mining. Journal of Cleaner Production. 55,56-66.

- Kaczala, F., Marques, M., Vinrot, E., Hogland, W., 2012. Stormwater run-off from an industrial log yard: characterization, contaminant correlation and first flush phenomenon. Environmental Technology. 33,1615-1628.

- Krook, J., Baas, L., 2013. Getting serious about mining the technosphere: a review of recent landfill mining and urban mining research. Journal of Cleaner Production. 55,1-9.

- Kurian, J., Esakku, S., Palanivelu, K., Selvan, A., 2003. Studies on landfill mining at solid waste dumpsites in India. In: Procceedings Sardinia'03, Ninth International Landfill Symposium, Cagliari, Italy. pp. 248-255.

- Laner, D., Crest, M., Scharff, H., Morris, J.W.F., Barlaz, M.A., 2012. A review of approaches for the long-term management of municipal solid waste landfills. Waste Management. 32,498-512.

- Long, Y-Y., Shen, D-S., Wang, H-T., Lu, W-J., Zhao, Y., 2011. Heavy metal source analysis in municipal solid waste (MSW): Case study on $\mathrm{Cu}$ and $\mathrm{Zn}$. Journal of Hazardous Materials. 186,1082-1087.

- Mahmoudkhani, M., Wilewska-Bien, M., Steenari, B-M., Theliander, H., 2008. Evaluating two test methods used for characterizing leaching properties. Waste Management. 28,133-141. 
- Masi, S., Caniani, D., Grieco, E., Lioi, D.S., Mancini, I.M., 2014. Assessment of the possible reuse of MSW coming from a landfill mining of old open dumpsites. Waste Management. 34,702-710.

- Palleiro, L., Rodríguez-Blanco, M.L., Taboada-Castro, M.M., Taboada-Castro, M.T., 2013. The influence of Discharge, $\mathrm{pH}$, Dissolved Organic Carbon, and Suspended Solids on the Variability of Concentration and Partitioning of Metals in a Rural Catchment. Water Air and Soil Pollution, 224,1651. Doi:, 10.1007/s1 1270-013-1651-9

- Parodi, A., Feuillade-Cathalifaud, G., Pallier, V., Mansour, A.A., 2011. Optimization of municipal solid waste leaching test procedure: Assessment of the part of hydrosoluble organic compounds. Journal of Hazardous Materials. 186,991-998.

- Slack, R.J., Gronow, J.R., Voulvoulis, N., 2005. Household hazardous waste in municipal landfills, Contaminants in leachate. Science of the Total Environment. 337,119-137.

- Slomczyńska, B., Slomczyński, T., 2004. Physico-chemical and Toxicological Characteristics of Leachates from MSW Landfills. Polish Journal of Environmental Studies. 13,627-637.

- Xiaoli, C., Shimaoka, T., Xianyan, C., Qiang, G., Youcai, Z., 2007. Characteristics and mobility of heavy metals in an MSW landfill: Implications in risk assessment and reclamation. Journal of Hazardous Materials. 144,485-491.

- Ziyang, L., Youcai, Z., Tao, Y., Yu, S., HuilI, C., Nanwen, Z., Renhua, H., 2009. Natural attrnuation and characterization of contaminants composition in landfill leachate under different disposing ages. Science of the Total Environment. 407,3385-3391. 